\title{
(2) OPEN ACCESS \\ ANCA-associated vasculitis can present with episodic attacks of joint pain consistent with palindromic rheumatism
}

\author{
Zoe Rutter-Locher 다, ${ }^{1}$ Bruce Kirkham, ${ }^{1}$ David P D'Cruz ${ }^{2}$
}

${ }^{1}$ Rheumatology, Guy's and St Thomas' Hospitals NHS Trust, London, UK

${ }^{2}$ Lupus Research Unit, Guy's and St Thomas' Hospitals NHS Trust, London, UK

Correspondence to Dr Zoe Rutter-Locher; zrutter-locher@nhs.net

Accepted 8 February 2021

Check for updates

(c) BMJ Publishing Group Limited 2021. Re-use permitted under CC BY-NC. No commercial re-use. See rights and permissions. Published by BMJ.

To cite: Rutter-Locher Z, Kirkham B, D'Cruz DP. BMJ Case Rep 2021:14:e240913. doi:10.1136/bcr-2020 240913

\section{SUMMARY}

A 64-year-old man with a 2-year history of palindromic rheumatoid arthritis, presented with recurrent flares of arthritis, weight loss, new onset Raynaud's phenomenon and one previous episode of small-volume haemoptysis. Investigations, including renal biopsy, revealed antineutrophil cytoplasmic antibodies-mediated vasculitis. This case highlights the need to consider vasculitis in patients in whom there is an atypical history of arthritis.

\section{BACKGROUND}

Antineutrophil cytoplasmic antibody (ANCA) associated vasculitis can be difficult to diagnose. Clinical presentation is variable, but usually there is systemic involvement including the upper respiratory tract, lower airway and kidneys. ${ }^{1}$ Arthralgia and arthritis occur in up to $50 \%$ of patients, ${ }^{1}$ most frequently in the large joints. However, arthritis is very rarely the initial presenting problem. ${ }^{2}$ Rheumatologists assessing patients in early inflammatory arthritis clinics may not be alert to the possibility of AASV. We describe a patient presenting with intermittent episodes of arthralgia diagnosed as palindromic rheumatism (PR) who subsequently evolved into AASV with crescentic glomerulonephritis. This case highlights the need to consider vasculitis in patients in whom there is an atypical history of arthritis.

\section{CASE PRESENTATION}

A 64-year-old man presented with recurrent flares of intense joint pains and swelling in his hands and feet, each episode lasting a day, with no joint symptoms between attacks. His symptoms had started 2 years previously when he had seen a rheumatologist and a diagnosis of PR was made. The joint pains were very steroid-responsive, but both hydroxychloroquine and sulphasalazine trials for at least 3 months had not reduced the frequency or severity of his attacks. On detailed questioning, over the preceding 1 year he had lost $10 \mathrm{~kg}$ in weight, developed Raynaud's phenomenon while skiing and he experienced one episode of smallvolume haemoptysis. He reported transient tender lower limb nodules, calf claudication symptoms and intermittent painful paraesthesia. He had no history of uveitis or inflammatory bowel disease and no other relevant medical or family history. He lived with his partner, was an ex-smoker and previous cocaine user.
On examination, his pulse was 90 beats/min, blood pressure $139 / 83 \mathrm{~mm} \mathrm{Hg}$, weight $85.9 \mathrm{~kg}$. Urine dipstick showed protein ++ , blood ++++ . Clinically, he was thin, but looked well. There were no rashes or palpable nodules. Cardiovascular, respiratory and abdominal examination were normal with normal peripheral pulses. Neurologically, there was no evidence of a neuropathy or myopathy and his Achilles tendons were pain free. There was small joint tenderness in the fingers, but no synovitis. Nailfold video capillaroscopy was normal.

\section{INVESTIGATIONS}

Investigations demonstrated a reduced estimated glomerular filtration rate of 48 , normocytic anaemia with haemoglobin $113 \mathrm{~g} / \mathrm{L}$ and mean corpuscular volume $86 \mathrm{fL}$. His eosinophils were $0.2 \times 10^{9} / \mathrm{L}$, platelets $266 \times 10^{9} / \mathrm{L}$ and white cell count $7.0 \times 10^{9} / \mathrm{L}$. Inflammatory markers were raised with erythrocyte sedimentation rate $47 \mathrm{~mm} /$ hour and $\mathrm{C}$ reactive protein (CRP) $48 \mathrm{mg} / \mathrm{L}$. Serum urate was normal.

In view of his atypical history and above blood results, an ANCA was sent. This revealed a strongly positive proteinase 3 (PR3) antibodies 219. Antinuclear antibody, extractable nuclear antigens, dsDNA and myeloperoxidase antibodies were negative with normal complement levels. Rheumatoid factor and anticylic citrullinated peptide antibody were negative. Two COVID-19 swabs, urine drug screen, hepatitis B and C, and HIV serology were negative.

A renal biopsy showed ANCA-mediated vasculitis (focal class) with $3(27 \%)$ cellular/fibrocellular crescents, mild acute tubular injury with focal red cell casts and 5\%-10\% interstitial fibrosis and tubular atrophy.

Lung function tests were entirely normal and CT chest showed non-specific subtle areas of ground-glass changes in the lower lobes of unlikely significance.

\section{OUTCOME AND FOLLOW-UP}

He was treated with a high dose of $60 \mathrm{mg}$ oral prednisolone and intravenous rituximab $1 \mathrm{~g} 2$ weeks apart with subsequent resolution of his joint symptoms, improvement in PR3 titres to 99 units/mL and normalisation of the CRP.

\section{DISCUSSION}

$\mathrm{PR}$ is a clinical syndrome characterised by recurrent episodes of pain and swelling, usually of the small 
joints of the hands. Flares of PR always resolve spontaneously and do not result in joint damage, distinguishing it from rheumatoid arthritis (RA), where joint disease is persistent, leading to radiographic bony erosions. ${ }^{3}$ Although it is a distinct entity to RA, up to $50 \%$ of patients do go on to develop persistent RA. ${ }^{4}$ However, little is known about the underlying pathophysiology, how to identify which patients will go on to develop RA and to what extent patients may develop other rheumatological conditions. To our knowledge, this is the first case of intermittent seronegative small joint arthritis, consistent with PR, which has resulted in a diagnosis of AASV. Although rare, there are reports of patients with rheumatoid factor positive persistent inflammatory arthritis who have developed AASV, but none of these patients presented initially with PR. ${ }^{5}$

\section{Learning points}

- We describe a patient with antineutrophil cytoplasmic antibody-associated vasculitis presenting with episodic attacks of joint pain consistent with palindromic rheumatism and deteriorating renal function secondary to crescentic glomerulonephritis.

- Without prompt diagnosis, this patient may have developed irreversible renal damage.

- Therefore, the importance of considering vasculitis in atypical rheumatological presentations is highlighted.
Contributors ZRL, BK and DPDC: Contributed to the conception and design of the manuscript. ZRL: Responsible for acquisition of the data and initial drafting of the manuscript. BK and DPDC: Edited the manuscript and gave final approval. ZRL, BK and DPDC: Agreed to be accountable for the manuscript.

Funding The authors have not declared a specific grant for this research from any funding agency in the public, commercial or not-for-profit sectors.

Competing interests None declared.

Patient consent for publication Obtained.

Provenance and peer review Not commissioned; externally peer-reviewed.

Open access This is an open access article distributed in accordance with the Creative Commons Attribution Non Commercial (CC BY-NC 4.0) license, which permits others to distribute, remix, adapt, build upon this work non-commercially, and license their derivative works on different terms, provided the original work is properly cited and the use is non-commercial. See: http://creativecommons.org/ licenses/by-nc/4.0/.

\section{ORCID iD}

Zoe Rutter-Locher http://orcid.org/0000-0001-8251-4037

\section{REFERENCES}

1 Hoffman GS, Kerr GS, Leavitt RY, et al. Wegener granulomatosis: an analysis of 158 patients. Ann Intern Med 1992;116:488-98.

2 Rodrigues CEM, Callado MRM, Nobre CA, et al. Wegener's granulomatosis: prevalence of the initial clinical manifestations--report of six cases and review of the literature. Rev Bras Reumatol 2010;50:150-64.

3 Mankia K, Emery P. What can palindromic rheumatism tell us? Best Pract Res Clin Rheumatol 2017;31:90-8.

4 Koskinen E, Hannonen P, Sokka T. Palindromic rheumatism: longterm outcomes of 60 patients diagnosed in 1967e84. J Rheumatol 1873e;2009:36.

5 Kısacık B, Önder ME, Sayarlıoğlu M, et al. Symmetric polyarthritis as an initial symptom in granulomatosis with polyangiitis: a report of six cases and review of the literature. Eur J Rheumatol 2018;5:191-3.

Copyright 2021 BMJ Publishing Group. All rights reserved. For permission to reuse any of this content visit

https://www.bmj.com/company/products-services/rights-and-licensing/permissions/

BMJ Case Report Fellows may re-use this article for personal use and teaching without any further permission.

Become a Fellow of BMJ Case Reports today and you can:

- Submit as many cases as you like

- Enjoy fast sympathetic peer review and rapid publication of accepted articles

- Access all the published articles

Re-use any of the published material for personal use and teaching without further permission

Customer Service

If you have any further queries about your subscription, please contact our customer services team on +44 (0) 2071111105 or via email at support@bmj.com.

Visit casereports.bmj.com for more articles like this and to become a Fellow 